\title{
Organic carbon, nitrogen pool and microbial abundance indifferent rice soils of Manipur valley, India
}

\author{
N. Bishworjit ${ }^{1 \star}$, T. Basanta Singh ${ }^{1}$, K. Nandini Devi ${ }^{2}$, K. Khamba Singh ${ }^{3}$ and M. Anandi Devi ${ }^{3}$ \\ ${ }^{1}$ Bidhan Chandra KrishiViswavidyalaya, Mohanpur -741252, West Bengal, India. \\ ${ }^{2}$ College of Agriculture, Central Agricultural University, Imphal-795001, Manipur, India. \\ ${ }^{3}$ Department of Biochemistry, Manipur College, Imphal, Manipur 795001, India.
}

Accepted 24 April, 2013

\begin{abstract}
A study was undertaken in three blocks of Manipur viz. Haorang, Wangoi and Sawombung after rice harvest covering upland, midland and lowland areas. The oxidizable organic carbon $(\mathrm{OC})$ of these soils was found to be fairly good and ranged from 5.0 to $18.1 \mathrm{~g} / \mathrm{kg}$. The average $\mathrm{pH}$ values of $5.72,5.45$ and 5.33 were noticed in the soils of Haorang, Wangoi and Sawombung blocks respectively. Significant relationships were observed between the organic carbon and mineralized nitrogen pools. The $\mathrm{NO}_{3}-\mathrm{N}$ content was found to be positively correlated with oxidizable OC $\left(r=0.335^{\star}\right)$, total $N\left(r=0.480^{\star *}\right)$ and $\mathrm{NH}_{4}-\mathrm{N}\left(r=0.818^{\star \star}\right)$ of these soils. The colony forming unit (CFU) of total viable bacteria (TVB), aerobic Non-Symbiotic nitrogen fixing bacteria (ANFB), phosphate solubilizing bacteria(PSB), actinomycetes and fungi varied widely. There was fair increase of microbial populations at $\mathrm{pH}=5.7$ and effect of $\mathrm{pH}$ was more for PSB and ANFB.The abundance of microbes in the three land types was as follows: uplandANFB $>$ TVB $>$ PSB >actinomycetes $>$ fungi; Midland- TVB> ANFB $>$ PSB $>$ actinomycetes $>$ fungi; and lowland -PSB > TVB>ANFB>actinomycetes> fungi.
\end{abstract}

Key words: Organic carbon (OC), nitrogen pool, microbial abundance, rice soil.

\section{INTRODUCTION}

Organic matter (OM) acts as the storehouse of essential nutrients and source or sink to atmospheric $\mathrm{CO}_{2}$ ( $\mathrm{Lal}$, 2002). An increase in soil organic carbon (OC) levels is directly linked to the amount and quantity of organic residues return to the soils (Mandal et al., 2007). indicated by higher microbial biomass and elevated soil respiration (Sparling et al., 2003). The soil solution concentration of $\mathrm{N}, \mathrm{P}, \mathrm{S}$ and several micronutrients are intimately related to organic fraction in soil (Havlin et al., 2005). Soil OC is the second largest carbon pool on the surface of the earth after the oceans (Batjes, 1996; Swift, 2001) and the possibility of increasing the OC content of the soil through changing agronomic management practices may play a role in combating climate change (Lal, 2002). It plays a key role in soil function, determining soil quality, water holding capacity and susceptibility of soil to degradation (Giller and Cadisch, 1997; Feller et al., 2001). The continuous transformations (mineralization) under the action of biological, chemical and physical factors make them to degrade. Decomposition of $\mathrm{OM}$ is important, as rapid decomposition of $\mathrm{OM}$ may lead to release of $\mathrm{N}$ as $\mathrm{NH}_{3}$. Prolonged submergence of soils for double or triple rice crops, on the one hand, may retard oxidation and also confer character of recalcitrance to soil organic carbon (Olk et al., 2002). In these soils, the relation between OC 
with different forms of soil nitrogen that is, $\mathrm{NH}_{4}-\mathrm{N}$ and $\mathrm{NO}_{3}-\mathrm{N}$ the $\mathrm{N}$ transformation system also gets deviated. These include crop $\mathrm{N}$ uptake dynamics, $\mathrm{N}$ fertilizer management, rainfall, irrigation, soil texture, and $\mathrm{N}$ transformations in the soil (Wang et al., 2010). However, the effect of this change in the soil microbial community on soil $\mathrm{N}$ transformation, especially the interactions of the soil fungal community with plant growth are not known ( $\mathrm{Li}$ et al., 2010). Nitrogen fractionation during mineralisation is controlled by carbon (C) and the $\mathrm{N}$ availability to the soil by microbial community (Dijkstra et al., 2006, 2008). They are also important for understanding the processes of soil C sequestration (Bronson et al., 2004). We attempted to assess the underlying relations of OC with different pools of $\mathrm{N}$ and to understand better how topographic change, variation in soil water submergence, and low soil acidity affect the diversity of microbial communities in rice soils.

\section{MATERIALS AND METHODS}

\section{Sampling site}

Manipur is wedged between hills from all sides and it is one among seven sister states of North-Eastern India. The state lies $790 \mathrm{~m}$ above $\mathrm{MSL}$, at $23^{\circ} 83^{\prime} \mathrm{N}$ to $25^{\circ} 68^{\prime} \mathrm{N}$ latitudes and $93^{\circ} 03^{\prime} \mathrm{E}$ to $94^{\circ} 78^{\prime}$ E longitudes with total area of $22,327 \mathrm{~km}^{2}$ and net cultivated area of $1,99,623$ ha. This hilly state receives heavy rains during May till the middle of October with an average annual rainfall of about 1468 $\mathrm{mm}$ favouring rain fed farming. All the soils under the study belong to Typic Haplaquent. Since decades, single rainfed rice crop predominate the study area. Normal transplanting was done after puddling where water is not limiting or by broadcasting where water scarcity existed. During late October to early November 2008, after rice harvest, we collected soil samples (0 to $15 \mathrm{~cm}$ depth) from dry fields by using core sampler. At each sampling site, 10 replica soil cores $(10 \mathrm{~m}$ apart) were collected and combined to make composite. It covered three selected blocks viz., Haorang, Wangoiand Sawombung making 15 composite samples. These soils were categorized based on the topography and duration of water stagnation during cropping season, that is, 3 upland soils included Maklang, Lairenkabi and Phayeng (foothill soils with gentle slope and submergence only during some crop stages of season); 7 midland soils included Lamsang, Awang Khunou, Lairenjam, Malom Tulihal, Thongdabi, Leimarok, Sakok, Waiton (water stagnation during rainy season to mid cropping season); 4 lowland soils included Hiyangthang, Langthabal, Khundrakpam, Takhel (where water stagnates in most of the cropping season). The samples varied from clay to loam with CEC ranging from 13.40 to $32.80 \mathrm{cmol} / \mathrm{kg}$ soil.

\section{Soil analysis}

Samples were measured for $\mathrm{pH}$ with the help of glass electrode (Jackson, 1973) after calibrating with standard buffer solution at room temperature. The oxidizable OC content of the soil samples was determined by rapid titration/wet oxidation method (Walkeley and Black, 1934). Total nitrogen contents of the soil samples were determined by the modified Kjeldahl method whereas $\mathrm{NH}_{4}-\mathrm{N}$ and $\mathrm{NO}_{3}-\mathrm{N}$ were estimated by distillation of extracts (Jackson, 1973). Nitrate nitrogen is determined in soil extract (dried at $55^{\circ} \mathrm{C}$ for 12 to16 $\mathrm{h}$ ) by Kjeldahl distillation in presence of Devarda alloy. In both the process the ammonium borate is formed which is indicated by change in colour from pink to green and it is titrated against standard $0.02 \mathrm{~N} \mathrm{HCl}$ turning to distinct pink as end point. Available phosphorus content of the soils was determined after extracting the samples with $0.03 \mathrm{~N} \mathrm{NH} 4 \mathrm{~F}$ in $0.025 \mathrm{~N} \mathrm{HCl}$ (Bray and Kurtz, 1945).

\section{Microbial population analysis}

The colony forming unit of TVB, ANFB, PSB, actinomycetes and fungi, present in the soils were enumerated following serial dilutions at $\left(\times 10^{5}\right),\left(\times 10^{4}\right),\left(\times 10^{4}\right),\left(\times 10^{4}\right)$ and $\left(\times 10^{3}\right)$, respectively and by pour plate method in their respective suitable media. The counting of the colonies of TVB, ANFB, PSB, actinomycetes and fungi as apparent on the respective plate was made after the lapse of requisite incubation period in the incubator at $30 \pm 1^{\circ} \mathrm{C}$. The TVB count was made on Thornton's agar medium (1922), ( $\mathrm{pH}$ adjusted to 7.4, after sterilization). Count of aerobic non-symbiotic nitrogen fixing bacteria (ANFB) was made in Jensen's (1930) nitrogen free agar medium ( $\mathrm{pH}$ adjusted to 7.0). The count of PSB was done by inoculating them in solidified Pikovskaya's medium, $\mathrm{pH}$ adjusted to 7.4 (Pikovskaya, 1948). Jensen's agar medium (Jensen's, 1930) was used for the enumeration of actinomycetes (pH adjusted to 6.5-6.6 after sterilization). Martin's rose Bengal streptomycin agar medium (Martin, 1950) was used for counting fungi. For this, a stock solution of streptomycin was prepared by dissolving $10.0 \mathrm{mg}$ of streptomycin in $2.0 \mathrm{ml}$ of distilled water of sterilized distilled water and was added to the medium at the time of plating.

\section{Statistical analysis}

The statistical analysis for various soil analytical data like mean, standard deviation, standard error mean, critical difference, correlation co-efficient, regression etc. were determined by SPSS (16.0). Correlation coefficient among $\mathrm{OC}$, total- $\mathrm{N}, \mathrm{NH}_{4}-\mathrm{N}$ and $\mathrm{NO}_{3}-\mathrm{N}$ were calculated at 1 and $5 \%$ levels of probability.

\section{RESULTS AND DISCUSSION}

\section{Soil organic carbon}

The oxidizable $\mathrm{OC}$ of these soils ranged from $5.00 \mathrm{~g} / \mathrm{kg}$ to as high as $18.10 \mathrm{~g} / \mathrm{kg}$ with an average of $7.54,9.24$ and $10.8 \mathrm{~g} / \mathrm{kg}$ in the soils of Haorang, Wangoi and Sawombung blocks, respectively (Table 1). Among them, the soil of Phayeng, Hiyangthang, Leimarok, Waiton and Khundrakpam showed high OC $(>10 \mathrm{~g} / \mathrm{kg})$. Highest OC was obtained in Hiyangthang $(18.1 \mathrm{~g} / \mathrm{kg})$ followed by Leimarok (16.3 g/kg).

The average $\mathrm{pH}$ value 5.72, 5.45 and 5.33 were noticed in the soils of Haorang, Wangoi and Sawombung blocks, respectively. Due to the release of weak organic acids during decomposition of organic matter might lower the $\mathrm{pH}$ of soil.

This drives soil into lower redox potentials by virtue of electron donation by organic substrates through enzymatic reactions. Highest accumulation of $\mathrm{OC}$ was found in lowland followed by midland and upland. With increase in oxidizable $\mathrm{OC}$ there was an increase in $\mathrm{N}$ pool in the soil (Figure 1). The increase in their contents was more for $\mathrm{NH}_{4}-\mathrm{N}$ as compared to $\mathrm{NO}_{3}-\mathrm{N}$. 
Table 1. Bock wise soil pH, organic carbon, total OC, nitrogen pool (ammonical, nitrate and total $\mathrm{N}$ ) and available phosphorus.

\begin{tabular}{|c|c|c|c|c|c|c|c|c|}
\hline Block & Location & $\mathrm{pH}$ & $\begin{array}{c}\text { Oxid. OC } \\
\left(\mathrm{g} \mathrm{kg}^{-1}\right)\end{array}$ & $\begin{array}{c}\text { Total OC } \\
\left(\mathrm{g} \mathrm{kg}^{-1}\right)\end{array}$ & $\begin{array}{c}\mathrm{NH}_{4}-\mathrm{N} \\
\left(\mathrm{mg} \mathrm{kg}^{-1}\right)\end{array}$ & $\begin{array}{c}\mathrm{NO}_{3}-\mathrm{N} \\
\left(\mathrm{mg} \mathrm{kg}^{-1}\right)\end{array}$ & $\begin{array}{l}\text { Total N } \\
\left(\mathrm{g} \mathrm{kg}^{-1}\right) \\
\end{array}$ & $\begin{array}{c}\text { Avl. P } \\
\left(\mathrm{mg} \mathrm{kg}^{-1}\right)\end{array}$ \\
\hline \multirow[t]{5}{*}{ Haorang } & Maklang & $5.82 \pm 0.02$ & $7.83 \pm 0.06$ & $10.4 \pm 0.05$ & $24.27 \pm 0.08$ & $18.44 \pm 0.08$ & $2.0 \pm 0.15$ & $11.34 \pm 0.01$ \\
\hline & Lamsang & $5.70 \pm 0.01$ & $7.40 \pm 0.30$ & $9.90 \pm 0.40$ & $22.57 \pm 0.14$ & $13.92 \pm 0.20$ & $1.7 \pm 0.05$ & $8.84 \pm 0.07$ \\
\hline & AwangKhunou & $5.59 \pm 0.01$ & $6.00 \pm 0.00$ & $8.00 \pm 0.00$ & $18.19 \pm 0.22$ & $11.38 \pm 0.06$ & $1.8 \pm 0.15$ & $19.51 \pm 0.09$ \\
\hline & Lairenkabi & $6.37 \pm 0.02$ & $6.13 \pm 0.15$ & $8.10 \pm 0.21$ & $28.90 \pm 0.15$ & $18.19 \pm 0.08$ & $2.2 \pm 0.10$ & $22.71 \pm 0.18$ \\
\hline & Phayeng & $5.10 \pm 0.03$ & $10.4 \pm 0.06$ & $13.9 \pm 0.06$ & $28.40 \pm 0.02$ & $12.79 \pm 0.16$ & $2.7 \pm 0.20$ & $12.51 \pm 0.08$ \\
\hline Mean & & 5.72 & 7.54 & 10.06 & 24.47 & 14.94 & 2.08 & 14.98 \\
\hline \multirow[t]{5}{*}{ Wangoi } & Hiyangthang & $4.96 \pm 0.01$ & $18.1 \pm 0.25$ & $24.2 \pm 0.35$ & $31.42 \pm 0.32$ & $18.12 \pm 0.23$ & $2.7 \pm 0.06$ & $16.37 \pm 0.12$ \\
\hline & Langthabal & $5.87 \pm 0.04$ & $5.00 \pm 0.20$ & $6.70 \pm 0.25$ & $15.24 \pm 0.05$ & $9.38 \pm 0.04$ & $1.3 \pm 0.20$ & $20.49 \pm 0.11$ \\
\hline & Lairenjam & $5.57 \pm 0.01$ & $6.73 \pm 0.06$ & $8.90 \pm 0.11$ & $18.24 \pm 0.28$ & $9.54 \pm 0.02$ & $1.4 \pm 0.15$ & $13.62 \pm 0.11$ \\
\hline & Malom & $5.63 \pm 0.02$ & $6.90 \pm 0.00$ & $9.20 \pm 0.00$ & $21.36 \pm 0.01$ & $13.22 \pm 0.16$ & $1.7 \pm 0.06$ & $25.17 \pm 0.15$ \\
\hline & Thongdabi & $5.21 \pm 0.01$ & $9.50 \pm 0.20$ & $12.7 \pm 0.25$ & $27.27 \pm 0.23$ & $15.67 \pm 0.02$ & $2.6 \pm 0.15$ & $11.16 \pm 0.13$ \\
\hline Mean & & 5.45 & 9.24 & 12.34 & 22.71 & 13.19 & 1.94 & 17.36 \\
\hline \multirow[t]{5}{*}{ Sawom-bung } & Leimarok & $5.22 \pm 0.02$ & $16.3 \pm 0.10$ & $21.8 \pm 0.10$ & $21.54 \pm 0.22$ & $13.49 \pm 0.21$ & $2.3 \pm 0.20$ & $18.03 \pm 0.14$ \\
\hline & Sakok & $5.58 \pm 0.07$ & $6.80 \pm 0.20$ & $9.10 \pm 0.25$ & $22.61 \pm 0.22$ & $13.62 \pm 0.01$ & $1.7 \pm 0.15$ & $20.88 \pm 0.09$ \\
\hline & Waiton & $5.74 \pm 0.06$ & $11.3 \pm 0.20$ & $15.1 \pm 0.30$ & $18.99 \pm 0.26$ & $11.71 \pm 0.26$ & $2.7 \pm 0.20$ & $17.18 \pm 0.01$ \\
\hline & Khundrakpam & $5.02 \pm 0.04$ & $10.3 \pm 0.65$ & $13.8 \pm 0.90$ & $25.41 \pm 0.30$ & $14.15 \pm 0.02$ & $2.3 \pm 0.20$ & $12.72 \pm 0.13$ \\
\hline & Takhel & $5.11 \pm 0.03$ & $9.33 \pm 0.06$ & $12.4 \pm 0.06$ & $23.48 \pm 0.19$ & $13.34 \pm 0.08$ & $1.9 \pm 0.15$ & $25.17 \pm 0.01$ \\
\hline Mean & & 5.33 & 10.8 & 14.44 & 22.41 & 13.26 & 2.18 & 18.80 \\
\hline SEm ( \pm ) & & 0.017 & 0.132 & 0.180 & 0.120 & 0.080 & 0.089 & 0.060 \\
\hline$C D(P=0.05)$ & & 0.049 & 0.381 & 0.520 & 0.347 & 0.231 & 0.257 & 0.173 \\
\hline$(P=0.01)$ & & 0.066 & 0.513 & 0.700 & 0.467 & 0.311 & 0.346 & 0.233 \\
\hline
\end{tabular}

Oxid. - Oxidizable, Avl. - Available, Yakovchenko VP, Sikora LJ, Milner PD (1998). Carbon and Nitrogen mineralization of added particulate and macro-organic matter. Soil Biol. Biochem. 30:2139-2146.

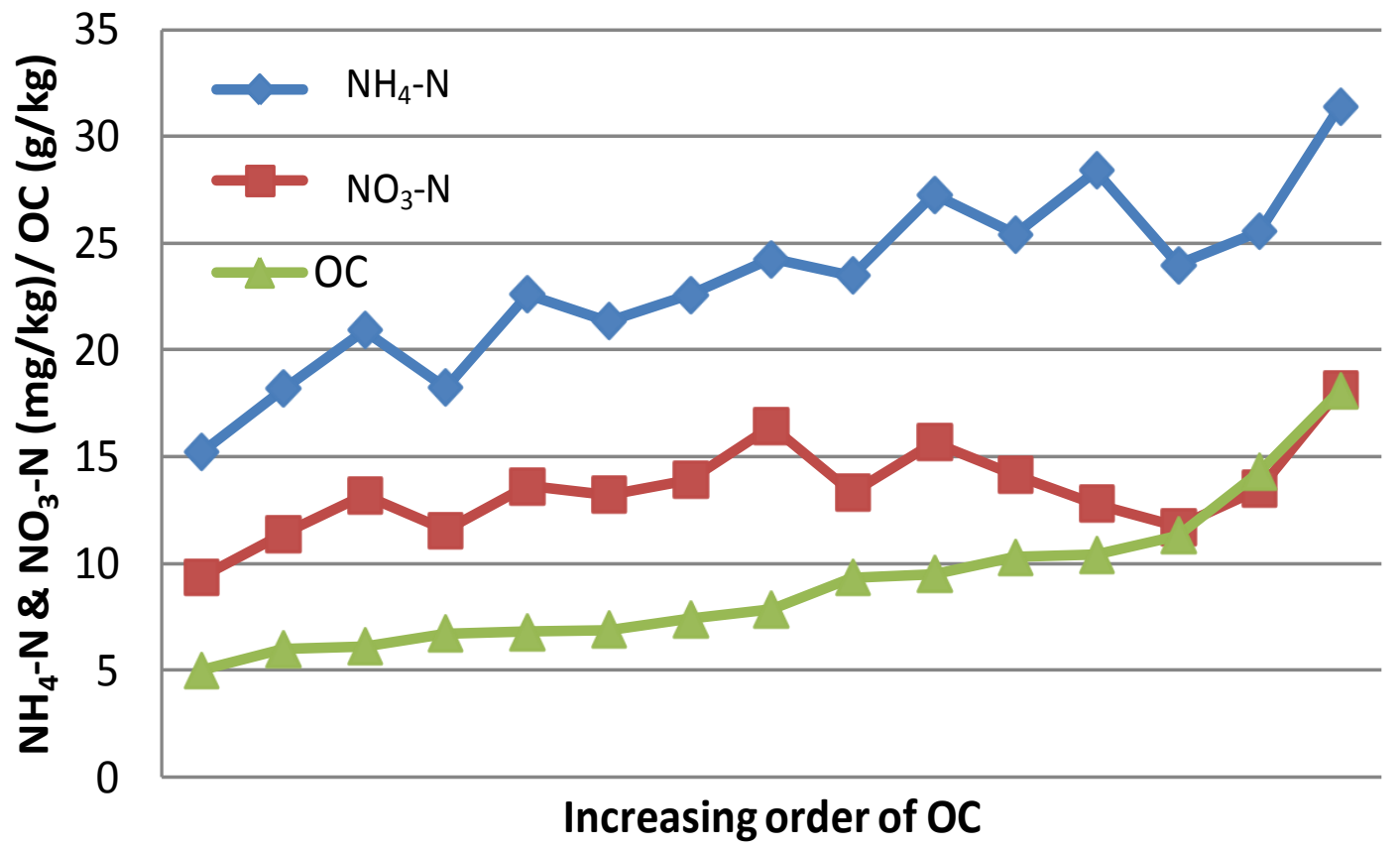

Figure 1. Increasing inorganic nitrogen pool with increasing organic carbon content. 


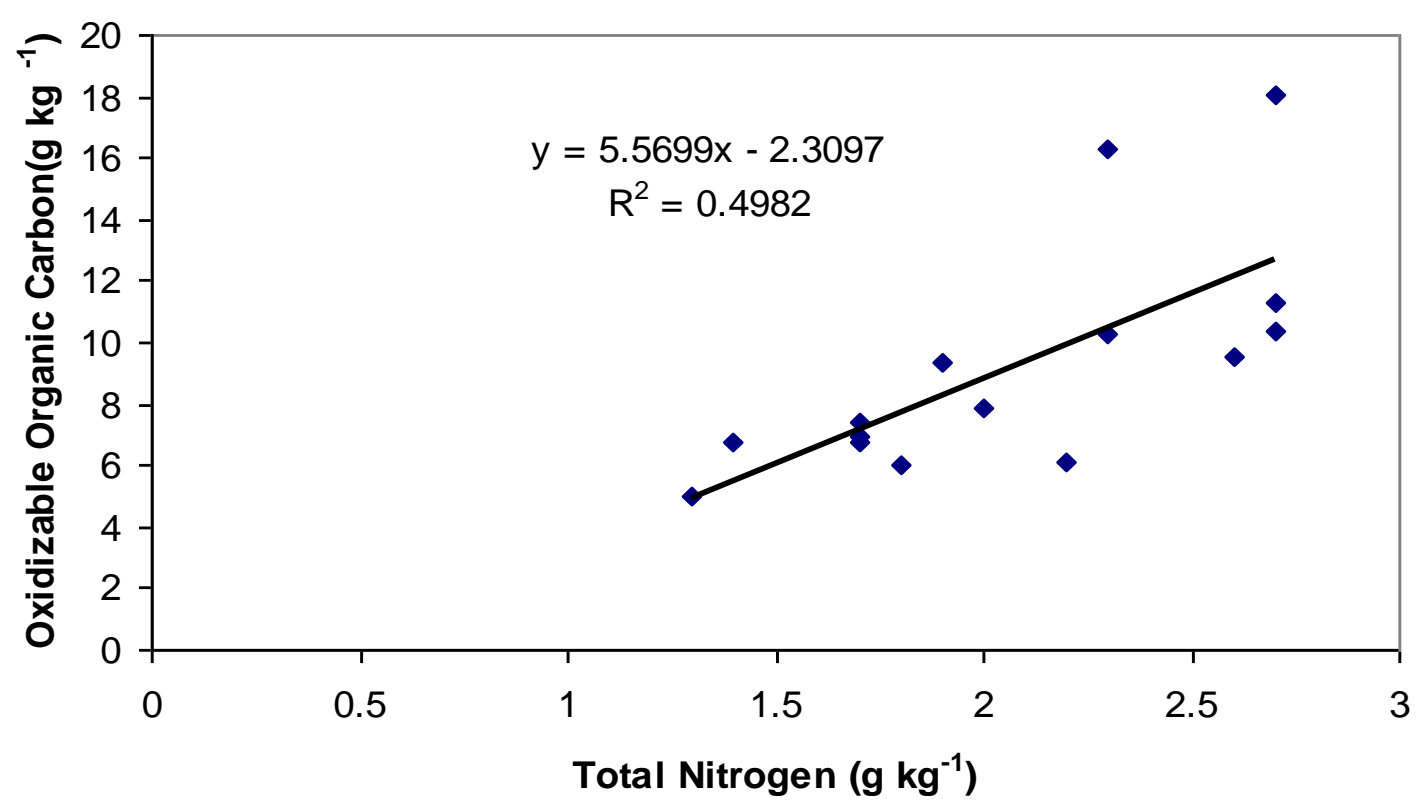

Figure 2. Linear regression line and corresponding regression of total- $\mathrm{N}$ and oxidizable $\mathrm{OC}$.

\section{Nitrogen pools in soil}

The analytical results of total- $\mathrm{N}, \mathrm{NH}_{4}-\mathrm{N}$ and $\mathrm{NO}_{3}-\mathrm{N}$ are presented in Table 1. The total- $\mathrm{N}$ contents in the soils of Haorang, Wangoi and Sawombung blocks were 2.08, 1.94 and 2.18, respectively. Out of fifteen locations, three locations of Haorang block viz. Phayeng, Lairenkabi and Maklang, two soils of Wangoi block viz. Hiyangthang and Thongdabi, and three soils of Sawombung block viz. Waiton, Leimarok and Khundrakpam have shown comparatively high in total- $\mathrm{N}$ content. The oxidizable OC of these soils were also found to be fairly high, which might be the reason for higher nitrogen. The OC is the principal reserve of $\mathrm{N}$ in the soil and some tropical soil may contain large quantities of mineral $\mathrm{N}$ in the top $2 \mathrm{~m}$ depth (Havlin et al., 2005). The macro organic matter additions to soil can result in $\mathrm{N}$ immobilization (Whalen et al., 2000) or increase in mineralization (Yakovchenko et al., 1998).

Ammonical nitrogen content in five soils of each block viz. Haorang, Wangoi and Sawombung were 24.47, 22.71 and $22.41 \mathrm{mg} / \mathrm{kg}$, respectively. Highest $\mathrm{NH}_{4}-\mathrm{N}$ $(31.42 \mathrm{mg} / \mathrm{kg}$ ) was obtained in the soil of Hiyangthang of Wangoi block followed by soils of Lairenkabi and Phayeng of Haorang block, Thongdabi of Wangoi block and Khundrakpam of Sawombung block. This indicated that the $\mathrm{NH}_{4}-\mathrm{N}$ contents in soils these three blocks were more or less accompanied with their total- $\mathrm{N}$ content. The $\mathrm{NO}_{3}-\mathrm{N}$ content in all the soils was found to be always lower than that of $\mathrm{NH}_{4}-\mathrm{N}$ content. This may be due to higher rate of ammonification than nitrification which is controlled by soil microorganisms. Nitrate nitrogen content of the five soils of each block viz.
Haorang,Wangoi and Sawombung varied from 11.38 to $18.44,9.38$ to 18.12 and 11.71 to $14.15 \mathrm{mg} / \mathrm{kg}$ with mean values of $14.94,13.19$ and $13.26 \mathrm{mg} / \mathrm{kg}$, respectively. Highest content of $\mathrm{NO}_{3}-\mathrm{N}(18.44 \mathrm{mg} / \mathrm{kg})$ was obtained in the soil of Maklang of Haorang. In other soils, the amount of $\mathrm{NO}_{3}-\mathrm{N}$ was also good. This indicated that $\mathrm{NO}_{3}-\mathrm{N}$ content of soils of the three blocks were not much varied and more or less accompanied with the total- $\mathrm{N}$ and $\mathrm{NH}_{4-}^{-}$ $\mathrm{N}$ content of those soils.

The large gap between total- $\mathrm{N}$ and mineralized nitrogen $\left(\mathrm{NO}_{3}+\mathrm{NH}_{4}-\mathrm{N}\right)$ an indication that there is large $\mathrm{N}$ reserve in these soils.

\section{Relationship among organic carbon, total- $\mathrm{N}, \mathrm{NH}_{4}-\mathrm{N}$ and $\mathrm{NO}_{3}-\mathrm{N}$}

The regression equation of oxidizable $O C$ and totalNindicated that, the minimum oxidizable $O C$ value observed was 2.3097 and increase with the value of $5.5699 \mathrm{~g} / \mathrm{kg}$ total- $\mathrm{N}$ for every unit increase in oxidizable OC (Figure 2). Similarly, the regression between oxidizable $\mathrm{OC}$ and $\mathrm{NH}_{4}-\mathrm{N}$ showed that, the minimum oxidizable OC value predicted was 0.1652 and increase with the value of $0.3896 \mathrm{mg} / \mathrm{kg}$ for every unit increase in oxidizable $\mathrm{OC}$ (Figure 3). And for $\mathrm{OC}$ and $\mathrm{NO}_{3}-\mathrm{N}$ indicated that, the minimum oxidizable $\mathrm{OC}$ value observed were $3.0706 \mathrm{~g} / \mathrm{kg}$ and increase with 0.4443 $\mathrm{mg} / \mathrm{kg}$ for every unit increase in oxidizable OC (Figure 4).

This showed the existence of positive correlation among them. The total- $\mathrm{N}$ content of the soils established highly significant correlation $\left(r=0.682^{* *}\right)$ with that of oxidizable OC content of the soils (Table 2). The content 


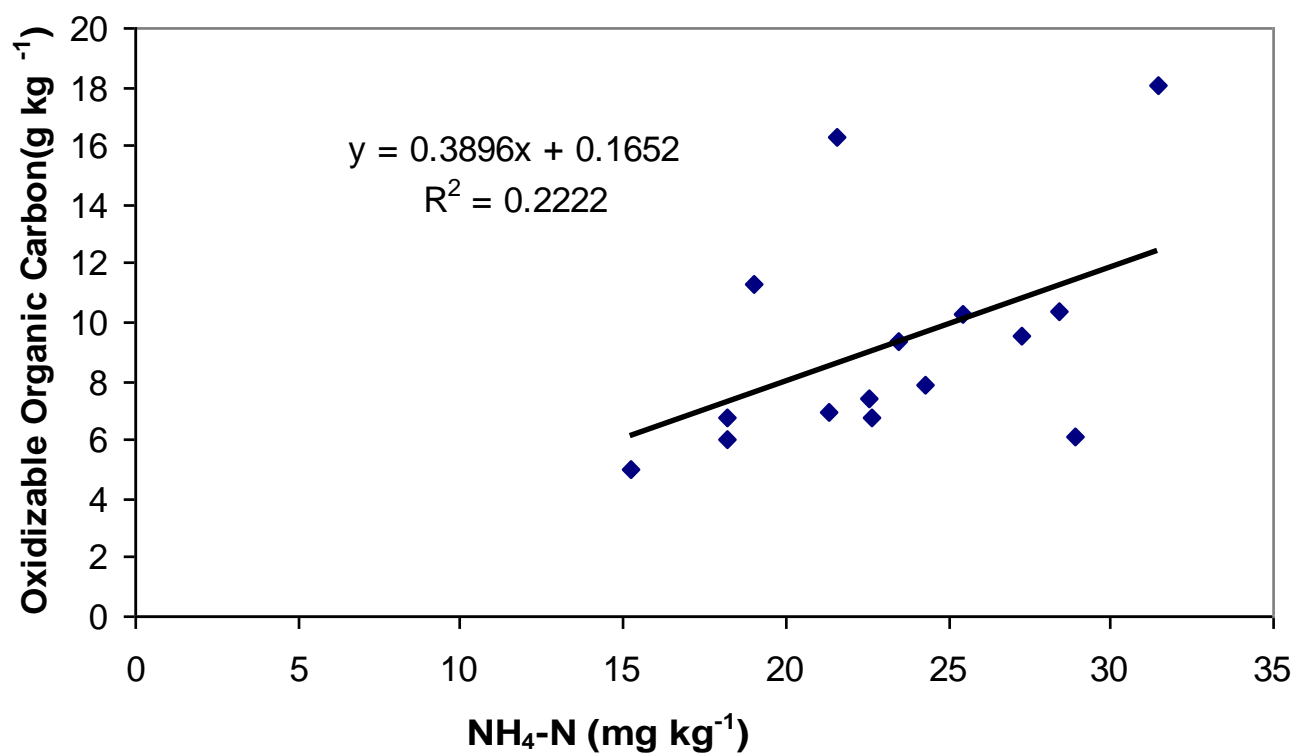

Figure 3. Linear regression line and corresponding regression of $\mathrm{NH}_{4}-\mathrm{N}$ and oxidizable $\mathrm{OC}$.

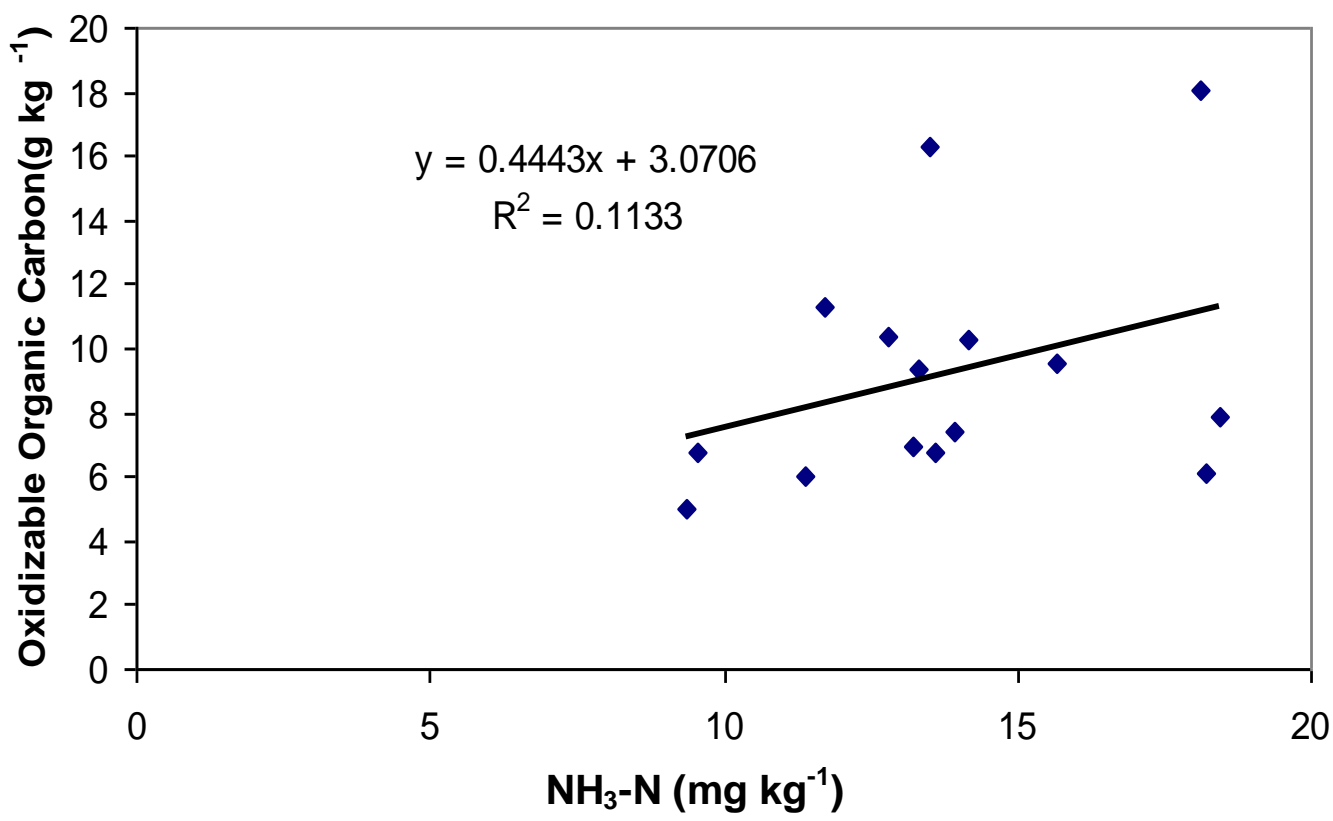

Figure 4. Linear regression line and corresponding regression of $\mathrm{NO}_{3}-\mathrm{N}$ and oxidizable $\mathrm{OC}$.

of the $\mathrm{NH}_{4}-\mathrm{N}$ was also found to be significantly correlated with total- $\mathrm{N}\left(r=0.667^{\star \star}\right)$ and oxidizable $\mathrm{OC}\left(\mathrm{r}=0.471^{* *}\right)$ of the soils. The regression equation between $\mathrm{NH}_{4}-\mathrm{N}$ and oxidizable OC (Figure 4) showed that, the minimum observed value of oxidizable OC was $0.1652 \mathrm{~g} / \mathrm{kg}$ and increase with $0.3896 \mathrm{mg} / \mathrm{kg}$ for every unit increase in $\mathrm{NH}_{4}-\mathrm{N}$. The $\mathrm{NO}_{3}-\mathrm{N}$ content was found to be positively correlated with oxidizable OC $\left(r=0.335^{*}\right)$, total- $N(r=$ $\left.0.480^{* *}\right)$ and $\mathrm{NH}_{4}-\mathrm{N}\left(r=0.818^{* *}\right)$ content of the soils.
Bronson et al. (2004) registered that, the potentially mineralizable $\mathrm{N}$ concentration was correlated with total soil $\mathrm{N}$ concentration $(r=0.73)$ to a similar degree as potentially mineralizable $\mathrm{C}$ was correlated with total soil $\mathrm{C}$ concentration $(r=0.70)$. And potentially mineralizable $\mathrm{N}$ concentration was moderately correlated with potentially mineralizable $\mathrm{C}(r=0.56)$. From the regression equation, between total- $\mathrm{N}$ and $\mathrm{NH}_{4}-\mathrm{N}$ (Figure 4) and $\mathrm{NO}_{3}-\mathrm{N}$ (Figure 6) showed to be all positively correlated and indicate that 
Table 2. Correlation coefficient ( $\mathrm{r}$ ) between oxidizable organic carbon and $\mathrm{N}$ pools in soil.

\begin{tabular}{lllll}
\hline \multicolumn{2}{l}{ Oxidizable OC } & Total $\mathrm{OC}$ & Total $-\mathbf{N}$ & $\mathbf{N H}_{4}-\mathbf{N}$ \\
\hline Total OC & $0.999^{* *}$ & & & \\
Total $-\mathrm{N}$ & $0.682^{* *}$ & $0.681^{* *}$ & & \\
$\mathrm{NH}_{4}-\mathrm{N}$ & $0.471^{* *}$ & $0.469^{* *}$ & $0.667^{\star *}$ & \\
$\mathrm{NO}_{3}-\mathrm{N}$ & $0.335^{*}$ & $0.334^{*}$ & $0.480^{* *}$ & $0.818^{* *}$ \\
\hline
\end{tabular}

** Significant at $\mathrm{P}=0.01$ * Significant at $\mathrm{P}=0.05$.

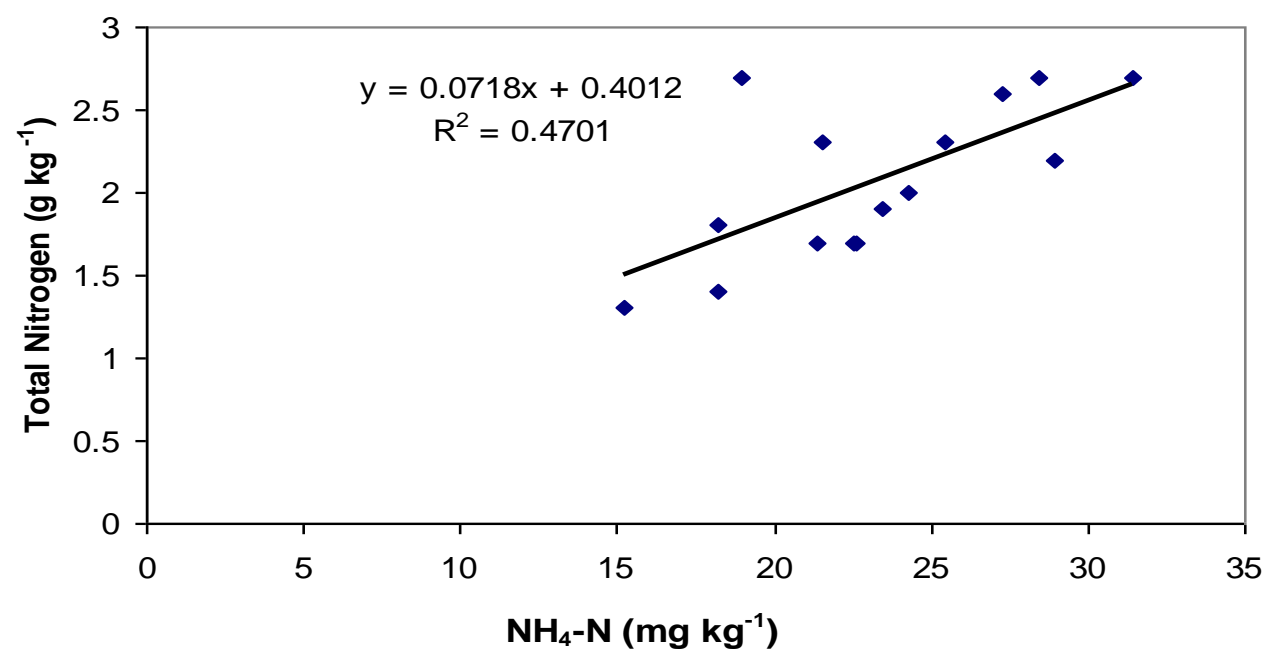

Figure 5. Linear regression line and corresponding regression of $\mathrm{NH}_{4}-\mathrm{N}$ and total- $\mathrm{N}$.

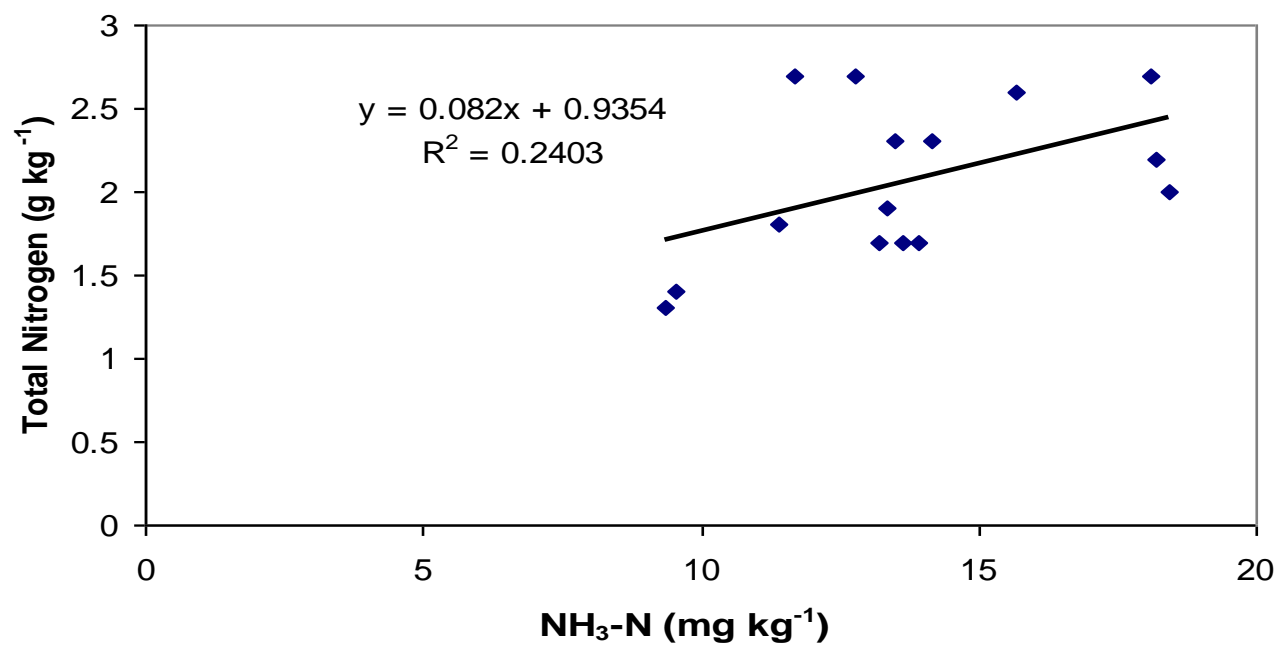

Figure 6. Linear regression line and corresponding regression of $\mathrm{NO}_{3}-\mathrm{N}$ and total-N.

the minimum values of total nitrogen are 0.4012 and $0.9354(\mathrm{~g} / \mathrm{kg})$ which increase with $0.0718 \mathrm{NH}_{4}-\mathrm{N}(\mathrm{mg} / \mathrm{kg})$ and $0.082 \mathrm{NO}_{3}-\mathrm{N}(\mathrm{mg} / \mathrm{kg})$ for every corresponding unit increase in total nitrogen respectively. The regression between $\mathrm{NH}_{4}-\mathrm{N}$ and $\mathrm{NO}_{3}-\mathrm{N}$ (Figure 7) also showed positive correlation with minimum value of $\mathrm{NH}_{4}-\mathrm{N}$ obtained was $5.15(\mathrm{mg} / \mathrm{kg})$ and rise of $1.3074 \mathrm{NO}_{3}-\mathrm{N}$ $(\mathrm{mg} / \mathrm{kg})$ for every corresponding unit increase in of ammonical nitrogen.

\section{Microbial populations}

The CFU of TVB, ANFB, PSB, actinomycetes and fungi 


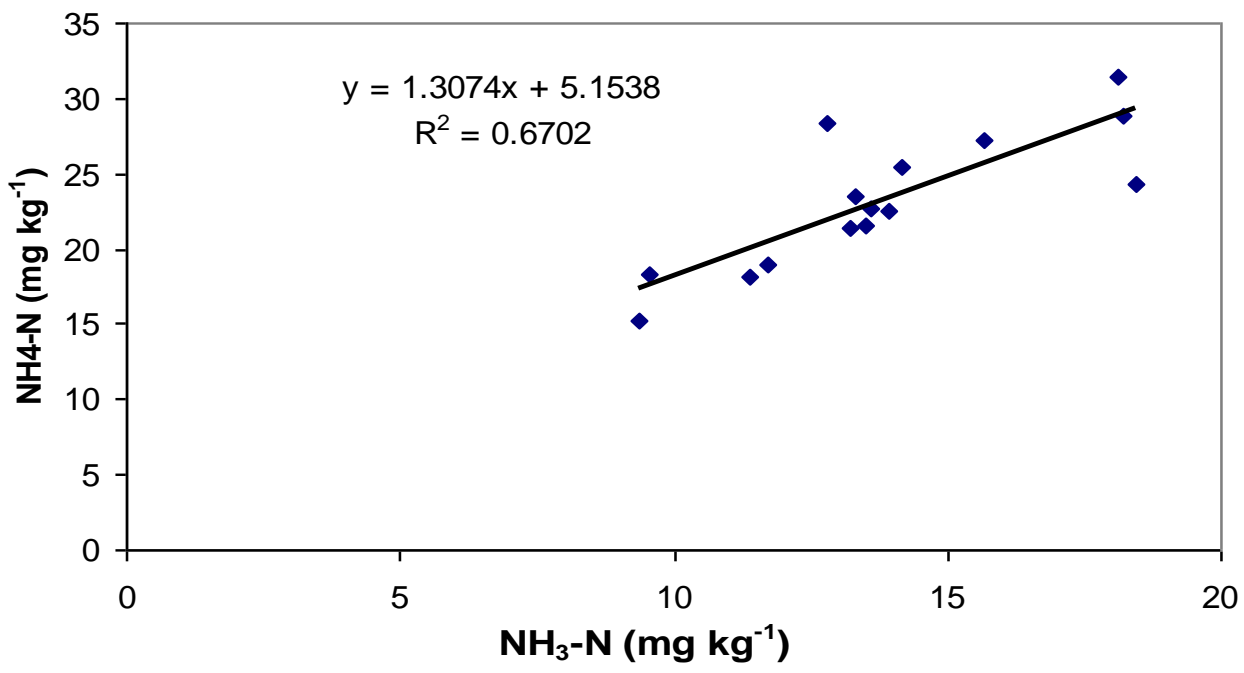

Figure 7. Linear regression line and corresponding regression of $\mathrm{NO}_{3}-\mathrm{N}$ and $\mathrm{NH}_{4}-\mathrm{N}$.

Table 3. Microbial CFU of three different rice soil groups.

\begin{tabular}{llccccc}
\hline Spot name & Land type & TVB & PSB & Actino-mycetes & Fungi & ANFB \\
\hline Lairenkabi & Upland & 192 & 83 & 84 & 54 & 143 \\
Maklang & Upland & 143 & 167 & 117 & 79 & 182 \\
Phayeng & Upland & 129 & 66 & 54 & 86 & 162 \\
Mean & & 154.67 & 105.33 & 85 & 73 & 162.33 \\
& & & & & & \\
Hiyangthang & Lowland & 182 & 113 & 86 & 85 & 89 \\
Khundrakpam & Lowland & 98 & 175 & 77 & 68 & 191 \\
Langthabal & Lowland & 173 & 190 & 161 & 68 & 182 \\
Takhel & Lowland & 104 & 101 & 83 & 93 & 90 \\
Mean & & 139.25 & 144.75 & 101.75 & 78.5 & 138 \\
& & & & & & \\
AwangKhunou & Midland & 101 & 97 & 75 & 99 & 125 \\
Lairenjam & Midland & 141 & 121 & 146 & 76 & 134 \\
Lamsang & Midland & 110 & 74 & 82 & 66 & 119 \\
Leimarok & Midland & 121 & 179 & 53 & 70 & 150 \\
Malom & Midland & 118 & 125 & 128 & 78 & 131 \\
Sakok & Midland & 136 & 131 & 122 & 66 & 167 \\
Thongdabi & Midland & 171 & 67 & 70 & 90 & 74 \\
Waiton & Midland & 181 & 111 & 98 & 93 & 96 \\
Mean & & 134.88 & 113.13 & 96.75 & 79.75 & 124.50 \\
\hline
\end{tabular}

varied widely, 98-192, 74-191, 66-190, 70-161 and 54-99 colonies, respectively (Table 3 ). Most of microorganisms increased their populations with increasing soil $\mathrm{pH}$. With increasing populations of PSB and ANFB did not have visible influence on available of $\mathrm{P}$ and $\mathrm{N}$-pools. Bacteria and ANFB was more abundant in upland followed by lowland and midland. In case of PSB and actinomycetes their abundance was in the order, lowland> midland> upland. For fungal population, lowland and midland has equal contributions and least for upland. But the three land types did not vary significantly in this regard. The abundance of microbial populations that is, CFU, in the three land types followed; upland - ANFB $>$ TVB $>$ PSB $>$ actinomycetes $>$ fungi; midland - TVB >ANFB> PSB $>$ actinomycetes $>$ fungi; and lowland - PSB $>$ TVB $>$ ANFB $>$ actinomycetes $>$ fungi (Figure 8).

\section{Conclusions}

Dynamics of $\mathrm{C}, \mathrm{N}$ and microbial abundance, especially in 


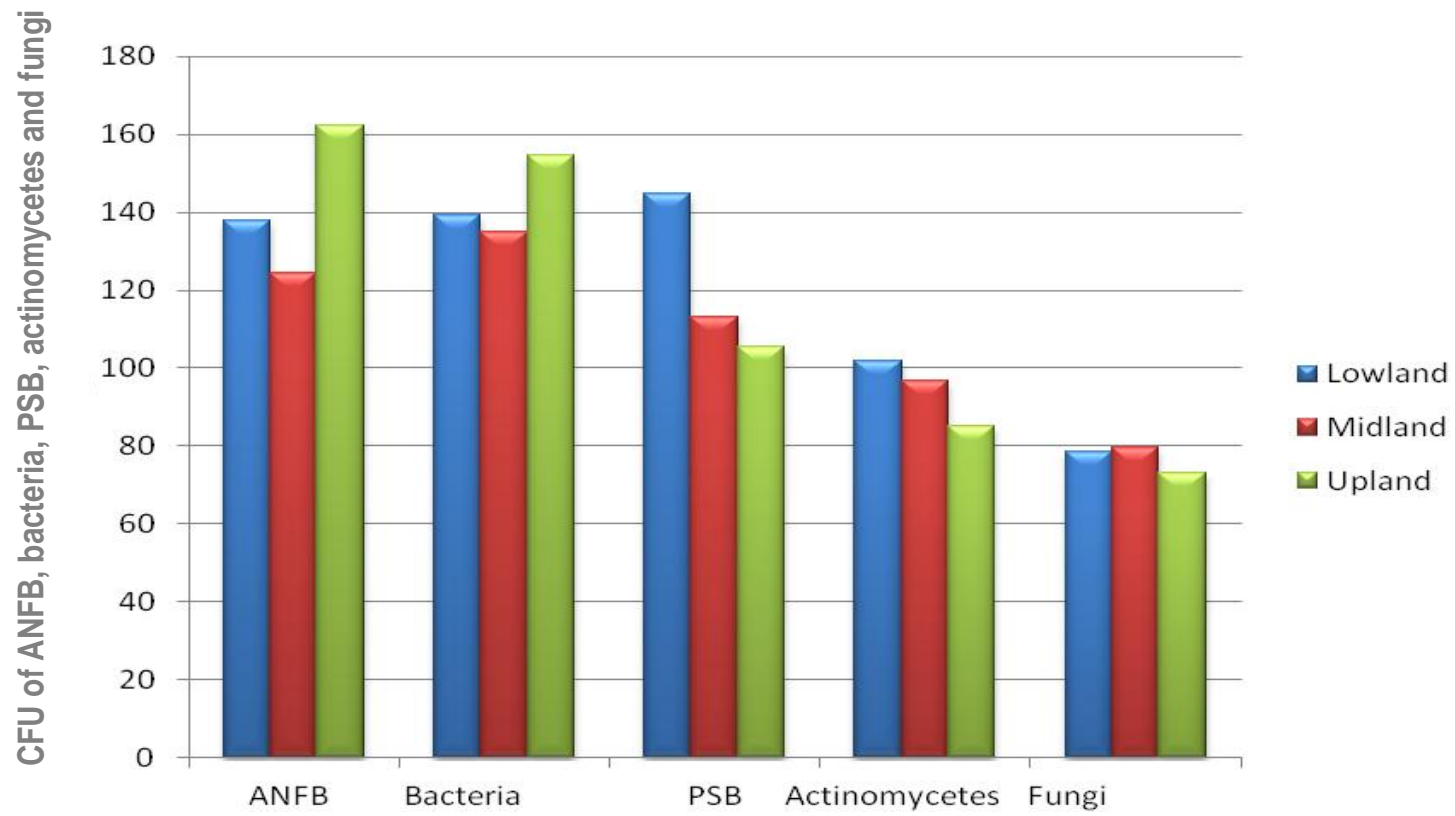

Figure 8. Dominance of microbial populations in lowland, midland and upland rice soils.

rice soils of Asia are important to study $C$ sequestration for increasing soil health and mitigating greenhouse gas emissions as the processes are mediated by microbes. From the above study, it may be concluded that, irrespective of land types, the oxidizable OC, total- $\mathrm{N}$, $\mathrm{NH}_{4}-\mathrm{N}$ and $\mathrm{NO}_{3}-\mathrm{N}$ in rice soils are positively correlated. The soils under the study has moderately high organic carbon content which constantly affects the growth of microbial population and their abundances influencing the equilibrium of nitrogen form in soil. Efficient management and utilization of organic matter in the rice and other arable soils may be the promise to increase soil resistance and resilience facilitating increase attributes of soil health or quality ultimately affecting carbon sequestration.

\section{ACKNOWLEDGEMENTS}

The authors are grateful to Bidhan Chandra KrishiVishwavidyalaya, West Bengal, India, especially to the Department of Agricultural Chemistry and Soil Science for the facilities and services provided for soil analysis.

\section{REFERENCES}

Batjes NH (1996). Total carbon and nitrogen in the soils of the world. Eur. J. Soil Sci. 47:151-163.

Bray RH, Kunz LT (1945). Determination of total organic and available forms of phosphorus in soils. Soil Sci. 59:39-45.

Bronson KF, Zobeck TM, Chua TT, Martinez-Acosta V, Pelt RSV, Booker JD (2004). Carbon and nitrogen pools of southern high plains cropland and grassland soils. Soil Sci. Soc. Am. J. 68:1695-1704.

Dijkstra P, LaViolette CM, Coyle JS, Doucett RR, Schwartz E, Hart SC,
Hungate BA (2008). ${ }^{15} \mathrm{~N}$ enrichment as an integrator of the effects of $\mathrm{C}$ and $\mathrm{N}$ on microbial metabolism and ecosystem function. Ecol. Lett. 11:389-397.

Dijkstra P, Menyailo V, Doucett RR, Hart SC, Schwartz E, Hungate BA (2006). $\mathrm{C}$ and $\mathrm{N}$ availability affects the ${ }^{15} \mathrm{~N}$ natural abundance of the soil microbial biomass across a cattle manure gradient. Eur. J. Soil Sci. 57:468-475.

Feller C, Balesdent J, Nicolardot B, Cerri C (2001). Approaching functional soil organic matter pools through particle-size fractionation examples for tropical soils. In: Assessment methods for soil carbon. (Eds. Lal R, Kimble KM, Follet RF). Adv. Soil Sci. pp. 53-67.

Giller KE, Cadisch G (1997). Driven by nature: a sense of arrival or departure. In: Driven by nature: plant litter quality and decomposition. (Eds. Cadisch G, Giller KE) (CAB International, Wallingford, UK). pp. 393-399.

Havlin JL, Beaton JD, Tisdale SL, Nelson WL (2005). Soil fertility and nutrient management: An introduction to nutrient management. $7^{\text {th }}$ Edition, Pearson/Prentice Hall. Upper Saddle River, NJ. P. 515.

Jackson ML (1973). Soil Chemical Analysis, Prentice Hall of India Private Ltd., New Delhi.

Jensen HL (1930) Azotobacteriaceae. Bact. Rev. 189:195-214.

Lal R (2002). The potential of soils of the tropics to sequester carbon and mitigate the greenhouse effect. Adv. Agron. 76:1-30.

Li X, Liu F, Li G, Lin O, Jensen CR (2010). Soil microbial response, water and nitrogen use by tomato under different irrigation regimes. Agric. Water Manag. 98:414-418.

Mandal B, Majumder B, Bandyopadhyay PK (2007). The potential of cropping systems and soil amendments for carbon sequestration in soils under long-term experiments in subtropical India. Global Chang. Biol. 13(2):357-369.

Martin JP (1950). Use of acid, rose bengal and streptomycin in the plate method for estimating soil fungi. Soil Sci. 69:332-349.

Olk DC, Dancel MC, Moscoso E, Jimenez RR, Dayrit FM (2002). Accumulation of lignin residues in organic matter fractions of lowland rice soils: A pyrolysis -GC-MS study. Soil Sci. 167:590-606.

Pikovskaya RI (1948) Mobilization of phosphorus in soil in connection with the vital activity of some microbial species. Mikrobiologiya 17: 362-370.

Sparling G, Parfitt RL, Hewitt AE, Schipper LA (2003). Three approaches to define desired soil organic matter contents. J. Env. Qual. 32:760-766. 
Swift RS (2001). Sequestration of carbon by soil. Soil Sci.166:858-871. Walkeley A, Black IA (1934). An examination of the Degjareff method for determining soil organic matter and a proposed modification of the chromic acid titration method. Soil Sci. 37:29-33.

Wang Q, Li F, Zhao, Zhang E, Shi S, Zhao W, Song W, Vance MM (2010). Effects of irrigation and nitrogen application rates on nitrate nitrogen distribution and fertilizer nitrogen loss, wheat yield and nitrogen uptake on a recently reclaimed sandy farmland. PI. Soil 337:325339.

Whalen JK, Bottomley PJ, Myrold DD (2000). Carbon and nitrogen mineralization from light and heavy fraction additions to soil. Soil Biol. Biochem. 32:1345-1352.
Yakovchenko VP, Sikora LJ, Milner PD (1998). Carbon and nitrogen mineralization of added particulate and macro-organic matter. Soil Biol. Biochem. 30:2139-2146. 